\title{
Personal growth initiative in relation to life satisfaction among university students
}

\author{
Inisiatif pertumbuhan personal dan perkaitannya dengan kepuasan hidup dalam \\ kalangan pelajar universiti
}

\author{
Amelia Mohd Noor*, Priyalatha Govindasamy, Nor Junainah Mohd Isa \\ Fakulti Pembangunan Manusia, \\ Universiti Pendidikan Sultan Idris, Tanjong Malim, Perak, Malaysia \\ *e-mail: amelia@fpm.upsi.edu.my
}

Received: 25 September 2020; Accepted: 10 December 2020; Published: 12 December 2020

To cite this article (APA): Mohd Noor, A., Priyalatha, G., \& Mohd Isa, N. J. (2020). Personal growth initiative in relation to life satisfaction among university students. EDUCATUM Journal of Social Sciences, 6(2), 42-49. https://doi.org/10.37134/ejoss.vol6.2.5.2020

To link to this article: https://doi.org/10.37134/ejoss.vol6.2.5.2020

\begin{abstract}
This study aimed to examine the relationship between personal growth initiative constructs which are planfulness, using resources, readiness to changes, and intentional behaviour on satisfaction with life. This study involved respondents comprising of 225 first-year university students. The data were gathered from a set of adapted questionnaire, namely Personal Growth Initiative Scale-II (PGIS-II) to measure university students' intentional process of personal growth and Satisfaction with Life Scale (SWLS) to measure their life satisfaction. Results showed that there were significant correlations among all fourconstruct of personal growth initiative and life satisfaction. The personal growth initiative was a significant predictor of which contributed $17.2 \%$ variance toward university students' life satisfaction. The findings give implication that university students with planfulness, using resources, readiness to changes, and intentional behaviour were more likely to experience satisfaction with their life. These elements of intentional growth of university students enable them to guide themselves toward completing their academic life with satisfaction. It is hoped that this study enlightens an understanding on the relationship between personal growth initiative and life satisfaction in the contex of higher educational academic setting in Malaysia.
\end{abstract}

Keywords: Personal Growth Initiative, Life Satisfaction, University Students

\section{ABSTRAK}

Kajian ini bertujuan untuk mengkaji hubungan antara inisiatif pertumbuhan personal iaitu perancangan, penggunaan sumber, kesediaan untuk berubah, dan tingkah laku bertujuan dengan kepuasan hidup. Kajian ini melibatkan respondens seramai 225 orang mahasiswa/i tahun pertama universiti. Data kajian dikumpul dengan menggunakan satu set soal selidik yang telah diadaptasi, iaitu Personal Growth Initiative Scale-II (PGIS-II) untuk mengukur proses pertumbuhan personal secara bertujuan dalam kalangan pelajar universiti dan Satisfaction with Life Scale (SWLS) untuk mengukur kepuasan hidup mereka. Hasil kajian menunjukkan bahawa terdapat hubungan yang signifikan di antara kesemua empat konstruk inisiatif pertumbuhan personal dengan kepuasan hidup. Inisiatif pertumbuhan personal juga merupakan peramal yang signifikan yang menyumbang sebanyak $17.2 \%$ varians terhadap kepuasan hidup pelajar universiti. Dapatan ini memberi implikasi bahawa pelajar universiti yang mempunyai perancangan, menggunakan sumber, mempunyai kesediaan untuk berubah, dan memiliki tingkah laku bertujuan cenderung untuk mengalami kepuasan dalam kehidupan mereka. Elemen-elemen ini menjadikan pelajar universiti dapat membimbing diri mereka sendiri ke arah menamatkan kehidupan pengajian akademik mereka dengan kepuasan. Kajian ini diharapkan dapat memberi pencerahan 
tentang pemahaman berkaitan hubungan antara inisiatif pertumbuhan personal dengan kepuasan hidup dalam konteks seting pengajian tinggi di Malaysia.

Kata kunci: Inisiatif Pertumbuhan Personal, Kepuasan Hidup, Pelajar Universiti

\section{INTRODUCTION}

University students are in a period of transition from adolescence to adulthood. According to Ilhan et al. (2019), the transition from higher-education to tertiary-education level constitutes a stage of challenging developmental life when young individuals experience major changes and this period of transition that can be one of the most stressful times in their lives. Furthermore, life in university is particularly demanding period whereby the university students facing and adapting within the present challenging responsibilities in order to balancing new and unfamiliar tasks, contexts, and relationships. Thus, process of transitioning may be even exacting to newcomers in university.

Cakir and Demirel (2019) stated that university students' life is filled with challenges and struggles and therefore being flexible and to have a positive wish to learn is quite important in one's life. Life satisfaction, which is a key to a happy and meaningful life, is a general evaluation of life quality based on an individual's choice (Diener, 1984). Specifically, satisfaction with life was defined as individual's perception and evaluation of one own life (Diener et al., 1985). Individuals with high satisfaction with life were found to be agregable with family and friends and to have higher academic achievement levels (Gilman \& Huebner, 2006). On the other hand, individuals with low satisfaction with life were found to have high levels of perceived stress, depression, and loneliness (Extremera et al., 2009; Kapikiran, 2012). Besides involving different eras in time that include past, current, and future satisfaction with life, the evaluation of life satisfaction is also related to the wish and willingness that an individual has to change his or her life (Diener et al., 1999; Appleton \& Song, 2008). Because life satisfaction is very closely associated in the promotion of healthy lifestyle choice (Grant et al., 2009), by the same token, the willingness to change attitude can be related to the pathways of skills for self-improvement, known as intentional personal growth (Robitschek 1998; 2003). According to Robitschek (1998), intentional personal growth is captured in the construct of personal growth initiative. Moreover, Robitschek proclaimed that "personal growth initiative can be describe as the intentional and active desire to grow in areas that are salient for a person." (1998; p.184). In detail, personal growth initiative is a set of intentional engagement skills that urgers individuals to pursue new challenges and growth that leading them to experience the feeling of fulfillment (Buyukgoze, 2015; Robitschek, 1998; 2003). Individuals with high levels of personal growth initiative typically have high levels of well-being, report more adaptive coping skills and better able to cope with life's development tasks, challenge themselves toward the desired changes and focus more on self-improvement. Whereas, individuals with low levels of personal growth initiative usually have low confidence with their ability regarding their life decision making (Robitschek 1998; Robitschek \& Keyes, 2009).

\section{RESEARCH OBJECTIVES}

The purpose of the present study is to examine personal growth intiative and its relation to life satisfaction among first-year university students. Specifically, the research objectives are:

1. to identify the levels of first-year university students' personal growth initiative and their satisfaction with life,

2. to examine the relationship between personal growth initiative and life satisfaction from first-year university students' perspectives, and

3. to investigate whether or not first-year university students' personal growth initiative may influence their satisfaction with life. 


\section{METODOLOGY}

\section{Research Design}

This study used quantitative research design, particularly correlational research. In correlational research, the degree of relationship is measured on two or more variables with the aim to predict the score on an outcome variable based on other score variable (Spatz \& Kardas, 2008). This correlation research is used to explain the relationship between personal growth initiative and life satisfaction and to what extent personal growth initiative predicts satisfaction with life.

\section{Population and Sampling}

Because the first-year university students facing more impacts regarding the transitional challenges from higher to tertiary educational levels (Ihhan et al., 2019), therefore, the target population for this study was the first-year university students from one of a public university in Malaysia. G*Power statistical software was used to conduct an a priori power analysis to determine the number of participants that represent an adequate sample size by taking into account the effect of size and statistical advantage (Faul et al., 2009). Using a purposive random sampling technique, a total sample of 225 first-year university students participated in this study.

\section{Instrumentation}

In order to collect the data in which align with the research objectives, a survey questionnaire was used in this study. The survey consists of three parts; part A, B, and C. Part A comprised of participants' demographic information. Whereas part B and $\mathrm{C}$ related to instruments that measure personal growth initiative and life satistifaction respectively.

Personal Growth Initiative Scale-II (PGIS-II) was developed by Robitschek (1999). This scale was used to measure first-year university students' intentional process of personal growth. The PGIS-II consists of 16-item with four subscales, namely planfulness, using resources, readiness to change, and intentional behavior. Each item was measured using a 5-point Likert scale ranging from 1 (strongly disagree) to 5 (strongly agree). Higher scores indicate higher level of intentional process of personal growth. This instrument is reported to have internal consistency, in which the Cronbach's alpha for the individual subscales ranged from .73 to .91 (Robitscheck \& Keyes, 2009).

Satisfaction with Life Scale (SWLS) was developed by Diener et al. (1985). This scale was employed in the present study to measure the global cognitive judgment of first-year university students' life satisfaction. The SLWS consists of 5-item that includes a 7-point Likert scale ranging from 1 (strongly disagree) to 7 (strongly agree). Higher scores indicate higher level of life satisfaction. With regard to reliability, the SWLS showed a degree of stability (Diener, et al., 1985), with an alpha of .87 across two-month period of test-retest reliability (Dordi \& Purande, 2018).

\section{Data Analysis}

The collected data was analyzed using IBM SPSS version 25. Prior to data analyses, data screening and examination were conducted. Descriptive statistics was used to anayze the data in general. To examine the relationship between personal growth initiative and life satistifaction, Pearson's correlation analysis and multiple regression analysis were the statistical tests were employed. 


\section{FINDINGS}

Descriptive statistics were used to report demographic characteristics. To determine the nature and strength of the relationship between personal growth initiative and life satisfaction, correlational analyses were performed by using the Person Product-Moment Correlation Coefficient. This study used Multiple Regression Analysis in order to investigate which elements of personal growth initiative were making a significant contribution in explaining the variance of first-year university students' life satisfaction.

\section{Profile of Participants}

Table 1 shows the demographic profile of the participants who participated in the present study. Of 225 first-year university students involved, the majority of the participants were female (73.3\%) and $26.7 \%$ were male. Although this study involved merely first-year university students, but their ages were varies. The response of the survey indicated that first-year university students ranging from 19 to 24 year-old of which depicted more than half particpants were 21 -year-old $(52.4 \%)$. This is followed by the age of 20 -year-old $(27.6 \%)$, 22-year-old (8.4\%), 23-year-old (5.3\%), 19-year-old (3.6\%), and 24-year-old (2.7\%).

Table 1: Demograhic profile of the particpants in the study $(n=225)$

\begin{tabular}{lcc}
\hline Category & $\boldsymbol{f}$ & $\boldsymbol{\%}$ \\
\hline Gender & 60 & \\
Male & 165 & 26.7 \\
Female & & 73.3 \\
Age & 8 & \\
19 & 62 & 3.6 \\
20 & 118 & 27.6 \\
21 & 19 & 52.4 \\
22 & 12 & 8.4 \\
23 & 6 & 5.3 \\
24 & & 2.7 \\
\hline
\end{tabular}

\section{Level of life satisfaction}

Table 2 portrays the mean and standard deviation obtained for the life satisfaction variable. Of 225 participants in this study, 3.1\% reported that they had low level of life satisfaction. Whereas $56 \%$ and $49.0 \%$ participants perceived their life satisfaction at high and moderate levels respectively.

Table 2: Level, average score, and standard deviation of life satisfaction $(n=225)$

\begin{tabular}{lcccc}
\hline Construct & $\boldsymbol{n}$ & \% & Mean & SD \\
\hline Life satisfaction & 7 & & 5.09 & 1.14 \\
Low & 92 & 3.1 & & \\
Moderate & 126 & 50.9 & & \\
High & 56.0 & & \\
\hline
\end{tabular}

\section{Level of personal growth initiative}

Generally, majority of the participants reported their intentional process of personal growth at high level $(83.1 \%)$. Based on Table 3, there were high levels of trend from the participants to initiate their personal growth process across all four elements of personal growth initiative (readiness to change $=89.8 \%$; using resources $=84.9 \%$; planfulness $=81.3$, and readiness to 
change $=76 \%$ ). The findings show that the readiness to change displayed the highest percentage at moderate level (23.6\%) and also depicted the only value at low level $(0.4 \%)$ as compared to the three other elements of personal growth initiative.

Table 3: Level, average score, and standard deviation of personal growth initiative $(n=225)$

\begin{tabular}{lcccc}
\hline Construct & $\boldsymbol{n}$ & $\boldsymbol{\%}$ & Mean & SD \\
\hline Personal Growth Initiative & & & 3.86 & .55 \\
(PGI-Total) & 0 & 0 & & \\
$\quad$ Low & 38 & 16.9 & & \\
$\quad$ Moderate & 187 & 83.1 & & \\
$\quad$ High & & & 3.86 & .66 \\
PGI- Planfulness & 0 & 0 & & \\
$\quad$ Low & 42 & 18.7 & & \\
$\quad$ Moderate & 183 & 81.3 & & \\
$\quad$ High & 0 & & & \\
PGI- Using Resources & 34 & 15.1 & 3.76 & \\
$\quad$ Low & 191 & 84.9 & & \\
$\quad$ Moderate & 1 & & & \\
$\quad$ High & 53 & 23.6 & 3.86 & \\
PGI- Readiness to Change & 171 & 76 & & \\
$\quad$ Low & & & & \\
$\quad$ Moderate & 0 & 0 & 4.03 & .59 \\
$\quad$ High & 23 & 10.2 & & \\
PGI- Intentional Behavior & 202 & 89.8 & & \\
$\quad$ Low & & & \\
$\quad$ Moderate & High &
\end{tabular}

Note. PGI = Personal growth initiative; PGI-P = Planfulness (PGI element); PGI-UR = Using resouces (PGI element); PGI-RtC = Readiness to change (PGI element); PGI-IB = Intentional behavior (PGI element); LS = Life satisfaction

Relationship between personal growth initiative and life satisfaction

Table 4: Correlation analyses result for the variables in the present study $(n=225)$

\begin{tabular}{lcccccc}
\hline & $\begin{array}{c}\text { PGI } \\
\text { (Total) }\end{array}$ & PGI-P & PGI-UR & PGI-RtC & PGI-IB & LS \\
\hline PGI (Total) & - & & & & & \\
PGI-P & .904 & - & & & & \\
PGI-UR & .748 & .602 & - & & & \\
PGI-RtC & .852 & .750 & .471 & - & - & \\
PGI-IB & .856 & .736 & .572 & .627 & - & \\
LS & $.376^{* *}$ & $.325^{* *}$ & $.372^{* *}$ & $.242^{* *}$ & $.356^{* *}$ & - \\
\hline
\end{tabular}

Note. PGI $=$ Personal growth initiative; PGI-P $=$ Planfulness $($ PGI element); PGI-UR $=$ Using resouces (PGI element); PGI-RtC = Readiness to change $($ PGI element); PGI-IB = Intentional behavior $($ PGI element); LS = Life satisfaction

** denotes the correlation is significant at the .01 level

Table 4 presents the correlation analyses result among personal growth initiative, all four personal growth initiative's elements and satisfaction with life. The results showed that there was a significant low positive correlation between personal growth initiative in general with life satisfaction $(r=.376, n=225, p<.01)$. Regarding four elements of personal growth initiative, the findings found that all four elements were significantly positively correlate with 
life satisfacting. Specifically, using resources element with life satisfaction $(r=.372, n=225$, $p<.01)$, intentional behavior element with life satisfaction $(r=.356, n=225, p<.01)$, planfulness element with life satisfaction $(r=.325, n=225, p<.01)$, and readiness to change element with life satisfaction $(r=.242, n=225, p<.01)$.

Table 5: Summary of multi regression analysis results for the relationship between personal growth initiative and life satisfaction $(n=225)$

\begin{tabular}{|c|c|c|c|c|c|c|}
\hline Model & $R$ & $R^{2}$ & $\mathbf{F}$ & b & SE-b & $\mathbf{t}$ \\
\hline Constant & .415 & $.172 *$ & 9.095 & 1.791 & & 3.456 \\
\hline Total PGI & & & & .565 & .271 & .583 \\
\hline PGI-P* & & & & -.008 & -.005 & -.028 \\
\hline PGI-UR* & & & & .294 & .172 & 1.221 \\
\hline PGI-RtC* & & & & -.224 & -.139 & -.763 \\
\hline PGI-IB* & & & & .225 & .117 & .707 \\
\hline
\end{tabular}

Note. The dependent variable was Life Satisfaction; PGI = Personal growth initiative; PGI-P = Planfulness (PGI element); PGI-UR = Using resouces (PGI element); PGI-RtC=Readiness to change (PGI element); PGI-IB = Intentional behavior (PGI element).

$*$ denotes the adjusted $R^{2}=.172,{ }^{*} p<.01$.

Table 5 shows the summarized result of Multiple Regression Analysis that was used to develop a model for predicting first-year university students' life satisfaction based on their personal growth initiative score and its four elements, including planfulness, using resources, readiness to change, and intentional behavior. A significant regression was found $\left(\mathrm{F}_{(5,219)}=9.095, p<\right.$ .000 ), with $R^{2}$ of .172 . University students predicted their life satisfaction is equal to $1.791+$ .565 (i.e., personal growth initiative score in general) +.294 (using resources element) +.225 (intentional behavior element) - .008 (planfulness element) - .224 (readiness to change element). Overall, the personal growth initiative had significantly predicted participants' satisfaction with life, in which was able to account for $17.2 \%$ of the variance in life satisfaction, $R^{2}=.172,90 \%$ CI.

\section{DISCUSSION}

Majority of the first-year university students perceived their intentional process toward personal growth at a high level. This finding was consistent with the previous studies in which found that university students rated their level of personal growth initiative at a high level (Bauer et al., 2014; Raphael \& Vargese, 2014). However, some studies found that the university students reported their personal growth intiative at moderate level (Buyukgoze, 2015; Malik, Yasin, \& Shahzadi 2013; Negovan, 2010). According to Robitschek and Keyes (2009), individuals with high levels of intentional process to personal growth typically have high levels of well-being and have better ability to cope with their lives developmental tasks.

Regarding the first-year university students' perception on their life satisfaction, it was found that majority of them perceived their satisfaction with life at two levels, namely: the moderate and high levels. Yet, there was no significant difference between those two levels of life satisfaction. In addition, a small percentage of first-year university students rated their satisfaction with life at low level. The previous research demonstrated that the level of life satisfaction among university or college students was differs based on their level of study, specifically their level of satisfaction with life is higher when they were at upper level of their study (Cakir \& Demirel, 2019; Dost, 2007). Although the present study only focuses on firstyear university students, it is assumed that the difference starting age may resemble the life satisfaction maturity as experience by university students when they entered the tertiaryeducation study. While there was not recognizably different in high-moderate level among firstyear university students on their satisfaction with life, but there was a small percentage who reported their life satisfaction at a low level. This finding may requires a further action from the 
student welfare management authoriries at university level with the aim to prevent increasing percentage of low level satisfaction of life. This may be construed that first-year university students may still need specific guidance in order to adapt themselves as university students at higher education setting.

The result of the study indicated that first-year university students' personal growth initiative was significantly correlated with their satisfaction with life. Specifically, the higher intentional process of personal growth perceived by first-year university students, then the higher their level of life satisfaction. Other researchers' findings also demonstrated that individuals with high level of personal growth initiative had high levels of psychological, emotional, and social well-being (Hardin et al., 2007; Robitschek \& Keyes, 2009). Because personal growth initiative composes cognitive processes and skills that help individuals intentionally engaging in theire personal growth behavior (Robitschek, 1999; 2005); hence, it is assumed that this cognitive awareness and the personal abilities may associate with positive endorsement attitude toward first-year university students' lives overall. Furthermore, Robitschek and Kashubeck (1999) stated that individuals with high levels of personal growth initiative have been linked to low levels of anxiety, depression, and othe emotional distress in general. Moreover, previous studies found that hopelessness and anxiety were negatively correlated with individuals' life satisfaction (Gundogar et al., 2007).

Life satisfaction is a cognitive evaluation of individuals' lives based on their own self-selected standard (Dordi \& Purandare, 2018). Therefore, it is assumed that this self-selected standard may relate to individuals' intentional life-developmental process in which align with the individuals' cogntive evaluation of life. According to Diener et al. (1999), satisfaction with life involves individuals who are willingness to change their life. With regard to what extent the personal growth initiative may predict first-year university students' life satisfactions, result showed that the intentional process of personal growth was a significant predictor to satisfaction with life, specifically using resources and intentional behavior elements. Although Robitschek's et al. (1999) proclaimed that the construct of personal growth initiative is related to a set of skills for self-improvement that includes cognitive and behavioral aspects, the present research finding only supported the behavioral aspects of initiative process of personal growth. Thus, within the finding of this study, first-year university students' cognitive evalution of life satisfaction was influenced by their intentional behavioral process of personal growth.

\section{CONCLUSION}

In conclusion, the finding of this study indicated that the personal growth initiative not merely associated with life satisfaction, but also influenced first-year university students' satisfaction with life. Participants reported both their personal growth initiative and life satisfaction at high level. Moreover, the strength of the significant relationship between intentional process of personal growth and life satisfaction indicated a weak correlation. Hence, a caution is needed for data generalization. Because personal growth initiative predicted small parts of first-year university students' life satisfaction, future research may collect the data from bigger sample size that represents higher education students and focus on other variables that potentially serve as predictors. Moreover, future researcher may expand the demographic profiles of university students. By taking consideration of all suggested area future research, it is hoped a more holistic prediction model of life satisfaction in the context of Malaysian university students may be obtained.

\section{REFERENCES}

Appleton, S. \& Song, L. (2008). Life satisfaction in urben China: Components and determinants. World Development, 36, 2325-2340.

Bauer, J. J., Park, S. W., Montoya, R. M., \& Wayment, H. A. (2014). Growth motivation toward two paths of eudemonic self-developemnt. Journal of Happiness Studies. 16, 185-210. 
Buyukgoze, H. (2005). An investigation of pre-service science and mathematics teachers' personal growth initiative. Acta Didacta Napocensia, 8, 47-53.

Cakir, V. O. \& Demirel, D. H. (2019) A student-oriented study: Analyzing the relationship between happiness and satisfaction with life. Journal of Educational Studies, 5, 150-161.

Diener, E., Emmons, R. A., Larsen, R. J., \& Griffin, S. (1985). The satisfaction with life scale. Journal of Personality Assessment, 49, 71-75.

Diener, E., Suh, E. M., Lucas, R. E., \& Smith, H. L. (1999). Subjective well-being: Three decades of progress. Psychological Bulletin, 2, 276-302.

Dordi M., \& Purandare, M. (2018). Life satisfaction, personal growth initiative and hope in alcoholics: A correlation study. Inidian Journal of Positive Psychology, 9, 427-431.

Dost, M. T. (2007). An examination of subjective well-being and life satisfaction of students attending to universities in South Africa and Turkey. Egitim ve Bilim, 35, 75-89.

Extremera, N, Duran, A., \& Rey, L. (2009). The moderating effect of trait meta-mood and perceived stress on life satisfaction. Personality and Individual Differences, 47, 116-121.

Faul, F., Erfelder, E., Buchner, A., \& Lang, A. (2009). Statistical power analyses using G*Power 3.1: Test for correlation and regression analyses. Behavior Research Method, 41, 1149-1160.

Gilman, R. \& Huebner, E. S. (2006). Characteristics of adolescents who report very high life satisfaction. Journal of Youth and Adolescence, 35, 293-301.

Grant, N, Wardle, J., \& Steptoe, A. (2009). The relationship between life satisfaction and health behavior: A cross-cultural analysis of young adults. International Journal of Behavioral Medicine, 16, 259-268.

Gundogar, D., Gul, S. S., Uskun, E., Demirci, S., \& Kececi, D. (2007). Invesatigation of the predictors of life satisfaction in university students. Clinical Psychiatry, 10-14-27.

Hardin, E.E., Weigold, I.K., Robistchek, C. (2007). Self-discrepancy and distress: The role of personal growth initiative. Journal of Counseling Psychology, 54, 86-92.

Ilhan, N., Guzluk, M., \& Ozmen, E. (2019). The relationship between mental health and basic need fulfillment of university students. Journal of Psychiatric Nursing, 4, 265-274.

Kapikiran, N. A. (2012). Positive and negative affectivity as mediator and moderator of the relationship between optimism and life satisfaction in Turkish university students. Social Indicators Research, 106, 333-345.

Malik, N. I., Yasin, G., \& Shahzadi, H. (2013). Personal growth initiative and self-esteem as predictors of academic achievement among students of technical training institues. Pakistan Journal of Social Science, 33, 435-446.

Negovan, V. (2010). Dimensions of students' psychological well-being and their measurement: Validation of a students' psychosocial well-being inventory. Europe's Journal of Psychology, 2, 85-104.

Rapheal, J., \& Vargese, P. K. (2014). Self-actualization and personal growth initiative among the teachers of adolescents. Academic Journal of Psychological Studies, 3, 432-441.

Robitschek, C. (1998). Further validation of the personal growth initiative scale. Measurement and Evaluation in Counseling and Development, 30, 183-198.

Robitschek, C. (1999). Further validation of the personal growth initiative scale. Measurement and Evaluation in Counseling and Development, 31, 197-210.

Robitschek, C. (2003). Validity of personal growth initiative scales score with a Mexican American college student population. Journal of Counseling Psychology, 50, 496-502.

Robitschek, C. \& Kashubeck, S. (1999). Structural model of parental alcoholism, family functioning, and psychological health: The mediating effects of hardiness and personal growth orientation. Journal of Counseling and Psychology, 46, 159-172.

Robitschek, C., \& Keyes, C. L. M. (2009). Keye's model of mental health with personal groth initiative as a parsimonious predictot. Journal of Counseling Psychology, 56, 321-329.

Spatz, C. \& Kardas, E. (2008). Research methods in psychology. New York, NY: McGraw-Hill. 